\title{
СУЧАСНИЙ СТАН ПРОФЕСІЙНОГО РОЗВИТКУ ФАХІВЦІВ ЯК СКЛАДОВОӤ НЕПЕРЕРВНОЇ ОСВІТИ: АНАЛІЗ ЗАКОНОДАВЧОЇ БАЗИ УКРАЇНИ
}

\author{
(C) С. Р. Бабушко
}

У статті розглянуто професійний розвиток фахівців з позицій педагогіки та представлено результати аналізу законодавчої бази України, яка регулює його механізми. 3 'ясовано, що держсавна політика 3 питань професійного розвитку фахівців та освіти дорослих потребує подальшого опраџювання та окреслено шляхи ї̈ удосконалення

Ключові слова: професійний розвиток фахівців, нормативно-правова база Украӥни, освіта дорослих, законодавча підтримка

The article dwells upon the employees' professional development as a pedagogical category and represents the results of the analysis of Ukraine's legislation which regulates its mechanism. It has been found out that the state policy in this field as well as in adult education requires being further worked at. There have been offered some ways of its improvement

Keywords: employees' professional development, Ukraine's legislation, adult education, legal state support

\section{1. Вступ}

У сьогоденній педагогічній практиці все більшої значущості набувають питання освіти дорослих, зокрема професійного розвитку фахівців. Донедавна професійний розвиток вважався суто економічною категорією. Його розглядали в рамках економічних дисциплін. Нині це складне, багатогранне поняття, що охоплює широке коло взаємопов'язаних педагогічних, психологічних, соціальних, економічних питань, привертає до себе все більшу увагу педагогів, оскільки містить у собі великий освітній потенціал.

У сучасних динамічних умовах розвитку нових технологій фахівець будь-якої сфери діяльності не може упродовж тривалого часу обходитися тією кваліфікацією, якої він набув, як це було в минулому. На зламі століть професійні знання, уміння та навички повинні неперервно оновлюватися, фахівець повинен бути конкурентоспроможним і мобільним. Ці вагомі якості він може набути лише професійно зростаючи, підвищуючи свою кваліфікацію та розвиваючись особистісно, тобто в рамках професійного розвитку. Звідси випливає актуальність досліджуваного питання.

\section{2. Постановка проблеми}

Професійний розвиток як складова неперервної фахової освіти потребує всебічного ретельного вивчення. Передусім, це стосується необхідності аналізу сучасного стану цього питання. Україна на шляху інтегрування до європейського простору, проводить широке коло реформ в усіх галузях, зокрема і в освітній. Відтак, дослідження того, як держава підтримує та сприяє професійному розвитку своїх фахівців, може стати індикатором успішності вирішення проблеми на державному рівні. 3 огляду на сказане, метою статті $є$ здійснення аналізу законодавчої бази України щодо урегулювання механізмів професійного розвитку фахівців та окреслення шляхів прогностичного розвитку досліджуваного питання.

\section{3. Огляд літературних джерел}

Професійний розвиток $є$ предметом уваги багатьох вітчизняних та зарубіжних наукових праць в області професійної педагогіки (Н. Мукан, Л. Пуховська, Н. Пазюра, О. Садовець; M. Dudzinski, T. Ganser ), менеджменту (В. Данюк, М. Мурашко, В. Петюх, С. Цимбалюк; M. Harris, L. A. Jerris), управління персоналом (О. Крушельницька, Д. Мельничук, Ф. Хміль; C. Gustafson, D. Cannon, P. Latham). Варто відзначити, що порівняльно-педагогічні дослідження репрезентують результати аналізу законодавчих документів, що регулюють досліджувані науковцями явища у різних країнах. Наприклад, серед багатьох питань Н. Бідюк досліджувала нормативно-правове забезпечення професійного навчання безробітних у США [1]; А. Каплун розглядав законодавчі питання системи підготовки кваліфікованих робітників у Болгарії та Польщі [2]; Н. Мукан висвітлила законодавчі документи, що регулюють професійний розвиток учителів загальноосвітніх шкіл у Великій Британії, Канаді та США [3]; у своїй науковій розвідці Н. Пазюра торкалася законодавчої бази Японії та Південої Кореї щодо урегулювання внутрішньо фірмової професійної підготовки виробничого персоналу [4]. Разом з тим, досліджуючи різні аспекти професійного розвитку, поза увагою дослідників часто залишалося його нормативно-правове 
забезпечення в Україні, або ж дослідники торкалися його побіжно.

\section{4. Аналіз законодавчої бази України 3} професійного розвитку фахівців в контексті неперервної освіти

Всебічний аналіз нормативно-правового забезпечення професійного розвитку фахівців у нашій державі розпочнемо із знакового документу для становлення професійного розвитку та механізмів його регулювання - указу Президента України від 3 серпня 1999 року. Цей указ заклав підвалини для визначення основних напрямів розвитку трудового потенціалу України. Зокрема, у сфері розвитку освітньої бази передбачався всебічний розвиток інтелектуальних, духовних та фізичних здібностей особистості, забезпечення ринку праці висококваліфікованою робочою силою шляхом:

- забезпечення доступної та безоплатної повної загальної середньої освіти у державних та комунальних навчальних закладах i надання можливостей отримання якісних знань в системі недержавних навчальних закладів;

- сприяння професійному самовизначенню та ефективній адаптації молоді до умов ринкової економіки;

- формування ринку освітніх послуг;

- посилення орієнтації системи професійнотехнічної, вищої та післядипломної освіти на підготовку, перепідготовку і підвищення кваліфікації кадрів відповідно до потреб, перш за все, регіональних ринків праці;

- створення умов для забезпечення доступності професійно-технічної та вищої освіти для всіх верств населення шляхом підготовки робітників і спеціалістів за державним замовленням;

- формування системи безперервного навчання шляхом впровадження ступеневої підготовки, забезпечення реалізації програм підвищення кваліфікації і перепідготовки кадрів, створення умов для самоосвіти;

- удосконалення нормативно-правової бази для професійного навчання персоналу на підприємствах відповідно до їх планів соціального розвитку, надання цим підприємствам державної підтримки;

- інтеграції професійно-технічної, вищої та післядипломної освіти України у міжнародну освітню систем [5].

Починаючи з 2000 року, в Україні здійснюється низка заходів щодо відновлення та активізації функціонування системи професійного навчання працівників, підвищення їх кваліфікації та професійного розвитку. Так, Кабінетом Міністрів України прийнято розпорядження від 24 січня 2001 р. № 13 "Про заходи щодо сприяння підприємствам в організації професійного навчання кадрів на виробництві" [6], спільним наказом Міністерства праці та Міністерства освіти та науки від 26 березня 2001 p. № 127/151 затверджено Положення про професійне навчання кадрів на виробництві [7]. При Міністерстві праці утворено міжвідомчу консуль- тативну раду з питань підготовки кадрів на виробництві, підготовлено і доведено до всіх зацікавлених центральних та місцевих органів виконавчої влади методичні рекомендації із зазначених питань, організовано цикл семінарських занять для працівників кадрових служб підприємств. Хоча ці законодавчі документи стосуються лише працівників на виробництві, можна вважати їх одними із засадничих нормативних документів, що законодавчо регулюють професійний розвиток персоналу.

Загалом, різні аспекти питання професійного розвитку фахівців частково регулюються також іншими законами України, а саме: законом "Про освіту", законом "Про професійно-технічну освіту", законом "Про вищу освіту", Положенням про ступеневу професійно-технічну освіту, затвердженим постановою Кабінету Міністрів України від 3 червня 1999 p. N 956, постановою Кабінету Міністрів України від 29 серпня 2003 р. N 1380 "Про ліцензування освітніх послуг", Положенням про порядок кваліфікаційної атестації та присвоєння кваліфікації особам, які здобувають професійнотехнічну освіту, затвердженим спільним наказом Мінпраці і МОН від 31 грудня 1998 р. N 201/469.

Хоча перелічені нормативно-правові акти не враховують усіх особливостей навчання працюючих громадян, не передбачають заходів щодо його стимулювання, на сьогодні вже спостерігаються позитивні зміни в динаміці обсягів підвищення кваліфікації працівників. Якщо в 1996 році 6,2 відсотка облікової кількості штатних працівників підвищили свою кваліфікацію, то в 2002 і 2004 роках цей показник становив відповідно 8 і 8,3 відсотка [8]. Кількість працівників, що підвищили свою кваліфікацію в 2007 році порівняно з 2006 роком, збільшилася на 80 тисяч і склала 9,2 \% до облікової кількості штатних працівників проти 8,6 \% у 2006 році [9]. Цифра у 8,6 \% від облікової кількості штатних працівників, котрі підвищили свою кваліфікацію у 2010 році наводиться представником вітчизняної кадрової служби О. Вакуленко [10]. Точних даних про кількість осіб, котрі підвищили свою кваліфікацію у 2011 році ми не знайшли. Однак, якщо врахувати, що у 2011 році по відношенню до 2010 року ця цифра зросла на 3,7 \% [11], то прості обчислення показують, що загалом у 2011 році $12,3 \%$ працівників підвищили свій професійнокваліфікаційний рівень. Вищевикладене представлено на рис. 1.

Як бачимо 3 гістограми, 3 кожним роком кількість працівників, що отримали певне навчання та підвищили свій професійний рівень, повільно, проте неухильно зростає. Разом з тим, показники $є$ значно нижчими від нормативних показників розвинених країн, в яких, наприклад, періодичність підвищення кваліфікації працівника становить близько одного разу на п'ять років (Європейські країни), раз на півтора роки (Японія) [10]. Як вказується у звітних даних, періодичність підвищення кваліфікації в середньому по Україні все ще залишається в 2,5 рази нижчою від необхідної, а в окремих галузях (сільському господарстві, оптовій і 
роздрібній торгівлі) - у 10-20 разів [8]. Це означає, що рівень кваліфікації значної кількості фахівців не відповідає вимогам сучасного виробництва, а система підвищення кваліфікації потребує подальшого розвитку та удосконалення.

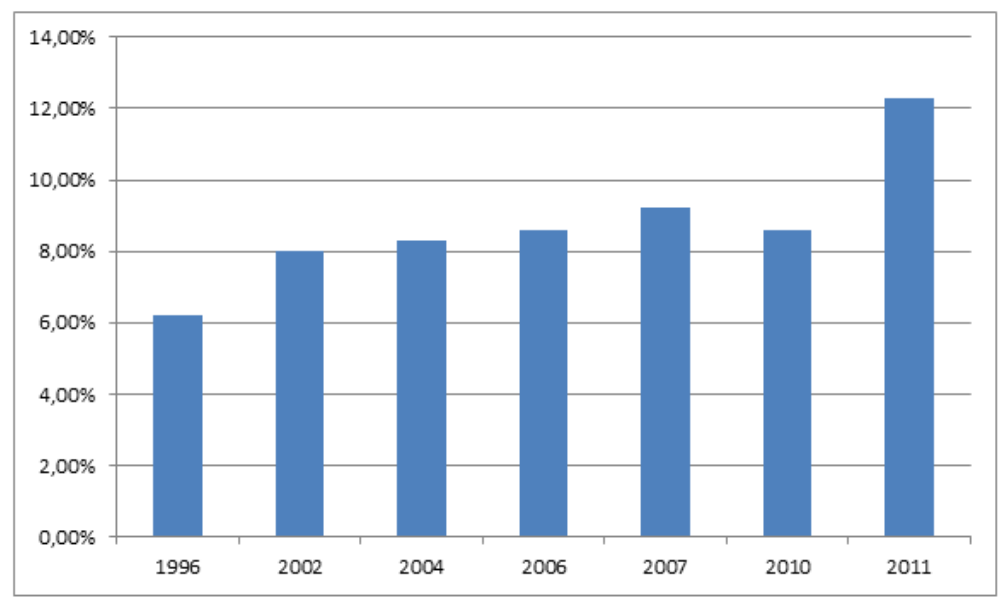

Рис.1. Дані про обсяги підвищення кваліфікації працівників в Україні (Джерело: систематизовано автором на основі опрацюювання [8-11])

Багато що вже зроблено і продовжує робитися в цьому напрямку. Зокрема, за ініціативою Міністерства праці та соціальної політики сумісно 3 такими соціальними партнерами, як Федерація працедавців та Федерація професійних спілок України, було розроблено «Концепцію розвитку системи підвищення кваліфікації працівників на період до 2010 року», схвалену розпорядженням Кабінету міністрів України від 20 березня 2006 р. № 158-р [8] та запропоновано для затвердження План заходів щодо іiі реалізації. Концепцією передбачено наступні напрями діяльності:

- удосконалення законодавчого забезпечення системи підвищення кваліфікації; Україні;

- розробка системи сертифікації персоналу в

- підвищення зацікавленості роботодавців у зростанні професійного рівня персоналу; ників;

- розробка системи стимулювання праців-

- удосконалення організації професійного навчання кадрів;

- поліпшення якості професійного навчання на виробництві.

На виконання Плану заходів щодо реалізації згаданої Концепції було розроблено відповідні Рекомендації щодо сприяння стимулюванню заінтересованості роботодавців у підвищенні професійного рівня працівників, затверджені наказом Міністерства праці та соціальної політики України від 3 грудня 2008 року №564 [9]. У Рекомендаціях мова йде про заходи, які доцільно здійснити 3 метою стимулювання розвитку професійного навчання працівників, а саме:

- фінансова підтримка підприємств у питаннях професійного навчання працівників;
- посилення відповідальності роботодавців за професійний рівень працівників;

- посилення відповідальності працівників за свій професійний рівень;

- підвищення ефективності використання коштів, спрямованих на професійне навчання працівників;

- створення умов для здійснення підприємствами професійного навчання працівників.

На наше переконання, всі згадані вище нормативно-правові документи заклали підвалини і сприяли появі такого вкрай необхідного закону, як Закону України «Про професійний розвиток працівників», який було прийнято Верховною Радою 12 січня 2012. Прийняття Закону стало ще одним важливим етапом в державному урегулюванні питань професійного розвитку вітчизняного кадрового корпусу. Законом передбачаються такі основні напрями діяльності роботодавців у сфері професійного розвитку:

- «розроблення поточних та перспективних планів професійного навчання працівників;

- визначення видів, форм i методів професійного навчання працівників;

- розроблення та виконання робочих навчальних планів і програм професійного навчання працівників; ників;

- організація професійного навчання праців-

- добір педагогічних кадрів та фахівців для проведення професійного навчання працівників безпосередньо у роботодавця;

- ведення первинного та статистичного обліку кількості працівників, зокрема тих, які пройшли професійне навчання;

- стимулювання професійного зростання працівників;

- забезпечення підвищення кваліфікації працівників безпосередньо у роботодавця або в навчальних закладах, як правило, не рідше ніж один раз на п'ять років;

- визначення періодичності атестації працівників та організація ії проведення;

- проведення аналізу результатів атестації та здійснення заходів щодо підвищення професійного рівня працівників» [12].

Оскільки працюючі - це категорія дорослих, то вважаємо за потрібне зупинитися також на нормативно-правових документах, що регулюють освіту дорослих в Україні. У провідних, економічно розвинених країнах (США, Канаді, багатьох європейських країнах) розроблено систему дієвих заходів, що покликані сприяти розвитку освіти дорослих: прийнято законодавчі акти, визначено шляхи розвитку, джерела фінансування і підтримки освіти дорослих, тобто сформовано комплексну законодавчу базу освіти дорослих. В Україні поки що 
відсутній закон про освіту дорослих, попри пї вагомість для особи, суспільства, держави. Однак, не можемо не відмітити, що в Україні також усвідомлюють вагомість освіти дорослих як пріоритетного напряму розвитку освіти в умовах сучасності. Адже освіта дорослих, зокрема неперервна професійна освіта працюючих, надзвичайно ефективна як для виробничої діяльності людини та для підприємства, на якому вона працює, так і для свого особистісного розвитку та для суспільства, в якому вона проживає. Працівник, в результаті свого навчання, повинен добре володіти не тільки професійними навичками, але й бути культурною, високоморальною, психологічно й технологічно грамотною, повною мірою відчувати себе особистістю, повноправним членом суспільства.

Ще в 2005 році в.о. Міністра освіти і науки України С. Ніколаєнко відзначав необхідність прийняття такого закону. За словами міністра, цей законодавчий акт сприятиме розширенню доступу до здобуття освіти громадянами України будь-якого віку, поліпшить рівень підготовки фахівців, надасть можливість кожній людині удосконалювати свої професійні знання й розвивати свої творчі уподобання, забезпечить багатогалузевий господдарський комплекс України кваліфікованими кадрами, вирішить ряд соціальних питань і матиме позитивне значення для підвищення освітнього потенціалу нації [13].

3 березня 2009 р. на засіданні бюро відділення професійної освіти i освіти дорослих Академії педагогічних наук України вітчизняною дослідницею освіти дорослих Л. Б. Лук'яновою був представлений проект Концепції освіти дорослих в Україні. Проект є проміжним варіантом, в якому викладено концептуальні положення освіти дорослих, тому його було відповідно названо «Концептуальні положення освіти дорослих» [14].

Про запровадження системного підходу до розв“язання проблем освіти дорослих та прийняття чіткої національної стратегії в цій сфері та доцільність прийняття закону «Про освіту дорослих» і відповідних підзаконних актах зазначалося також у Національній доповіді про стан і перспективи розвитку освіти в Україні в 2011 році [15]. Вагомим для нашого дослідження в законі буде постулат про відображення економічного стимулювання роботодавців щодо розвитку і здійснення професійного навчання персоналу підприємств, установ і організацій.

Загалом, на нашу думку, реформування освіти дорослих в Україні здійснюється повільними темпами, оскільки до сих пір відповідного закону не має. Проте, Міністерство освіти та науки України вже завершило роботу над проектом Закону України «Про післядипломну освіту», який було оприлюднено 13 листопада 2013 року [16]. Певною мірою у проекті відображено деякі питання освіти дорослих та до професійного розвитку фахівців. Законопроект розроблено на виконання Націо-нального плану дій на 2013 рік щодо впровадження Програми економічних реформ на 2010-2014 роки «Заможне суспільство, конкурентоспроможна економіка, ефективна держава», затвердженого Указом Президента України від 12 березня 2013 року № 128, та Плану заходів щодо реалізації у 2013 році положень Стратегії державної кадрової політики на 2012-2020 роки, затвердженого Указом Президента України від 23 квітня 2013 р. № 229.

Згідно проекту Закону реалізація державної політики у сфері післядипломної освіти забезпечується шляхом:

- забезпечення професійного розвитку працівників;

- забезпечення роботодавців до навчання працівників;

- збереження i розвитку системи післядипломної освіти та підвищення якості післядипломної освіти;

- урахування особливостей структури і змісту освітніх потреб громадян на різних стадіях впродовж життя;

- удосконалення системи професійного навчання впродовж життя 3 урахуванням інтересів особистості, потреб економіки та ринку праці [16].

Перші два шляхи безпосередньо стосуються нашого дослідження. Однак, оскільки професійний розвиток працівників та забезпечення роботодавцями навчання свого персоналу може здійснюватися не обов“язково у закладах післядипломної освіти, в проекті закону мова йде про два види післядипломної освіти: формальну та неформальну. Під нефоммальною післядипломною освітою розуміють набуття особою професійних знань, умінь, інших компетентностей, не регламентоване місцем набуття, строком та формою навчання; а формальна післядипломна освіта - це набуття особою професійних знань, умінь, інших компетентностей у закладі післядипломної освіти (або підрозділі післядипломної освіти навчального закладу), підприємства, установи, організації (роботодавця) відповідно до програм післядипломної освіти, за результатами якого видається документ про післядипломну освіту встановленого державою зразка [16]. Таким чином, якщо особа отримує навчання на місці свого працевлаштування, це можна вважати неформальною післядипломною освітою. Але, якщо ця особа не має диплому, то вже некоректно використовувати термін «післядипломна освіта» по відношенню до особи без диплому, але яка навчається під час виконання своїх безпосередніх трудових обов'язків. Безумовно, такі недоладності можуть бути усунені в рамках закону «Про освіту дорослих».

\section{5. Апробація результатів дослідження}

Все вище викладене, дає всі підстави вважати, що в арсеналі вітчизняного законодавства наявні деякі нормативно-правові документи, які стосуються досліджуваної проблеми та які ефективно діють. Однак, їх розрізненість заважає створенню цілісної системи, яка має місце в низці європейських країн, США, Канаді. Зокрема, в США та Канаді нормативно-правові документи, які стосуються навчання працівників та їх професійного розвитку, представ- 
влено в комплексі законів та підзаконних актів про працю та зайнятість, про людські ресурси, власне про професійне навчання та розвиток та про освіту дорослих, то в Україні питання висвітлено частково лише в документах про працю та трудових відносинах, законодавчих документах про освіту та Законі «Про професійний розвиток працівників». Законодавчої підтримки не мають поки що освіта дорослих, в рамках якої переважно здійснюється професійний розвиток фахівців, та розвиток людських ресурсів.

Відсутність цілісності урегулювання та унормування навчання працівників та їх професійного розвитку на законодавчому рівні унеможливлює забезпечення виваженої державної політики з питань професійного розвитку працівників. Як результат, рівень кваліфікації значної кількості працівників в Україні не відповідає вимогам сучасного ринку, а система підвищення кваліфікації кадрів та механізми професійного розвитку працівників потребують подальшого удосконалення та державної правової підтримки. Особливо це стосується фінансової підтримки. На відміну від США та Канади, в яких є відповідні закони щодо фінансового забезпечення навчання працівників, в Україні обов'язки 3 фінансування такого навчання покладаються лише на роботодавця. Тому значна кількість підприємств, організацій та компаній, зокрема малого та середнього розміру, не мають можливості підвищувати кваліфікацію свого персоналу відповідно до зростаючих вимог сучасного виробництва i сфери послуг.

Підсумовуючи вище викладене, доходимо висновку, що в Україні вже почала формуватися нормативно-правова база, яка регулює навчання та професійний розвиток працівників. Водночас не можемо не погодитися із думкою вітчизняної дослідниці Н. Пазюри, про те, що в Україні поки що створення системи внутрішньофірмової підготовки персоналу є справжнім викликом [4]. Адже існуючі закони, підзаконні акти, інші нормативні документи не враховують цілу низку питань, зокрема:

- особливості навчання та професійного розвитку працівників, як дорослих учнів;

- підготовка кваліфікованого педагогічного персоналу для здійснення внутрішньоорганізаційного навчання працівників;

- питання фінансового характеру від того, хто інвестує у навчання свого персоналу, до мотивації працівників у вигляді грошової підтримки;

- визнання результатів неформального навчання працівників;

- соціальне партнерство урядових, освітніх закладів та підприємств;

- стимулювання працівників до неперервного професійного розвитку.

\section{6. Висновки}

Таким чином, щоб упоратися із згаданим викликом та врахувати перераховані вище питання необхідна законодавча підтримка 3 боку держави, спрямована на всебічну підтримку та подальший розвиток системи навчання та професійного розвитку фахівців будь-якої сфери діяльності.

В контексті сказаного, особливої значущості набувають наукові дослідження у цій царині. Вивчення і використання прогресивного досвіду зарубіжних країн, в яких діє виважена, апробована, а відтак ефективна система нормативно-правових документів, націлених на сприяння та підтримку внутрішньоорганізаційного навчання працівників та їх професійного розвитку, створять необхідні теоретико-методологічні засади для розробки відповідних нормативних документів у вітчизняній практиці.

\section{Література}

1. Бідюк, Н. М. Теорія i практика професійного навчання безробітних у США [Текст]: дис. ... д-р пед. наук: спец. 13.00.04 / Н. М. Бідюк. - К., 2009. - 544 с.

2. Каплун, А. В. Розвиток систем підготовки каліфікованих робітників у Болгарії і Польщі (кінець XIX-XX ст.) [Текст]: дис. ... д-р пед. наук: 13.00 .04 / А. В. Каплун. - К., $2011-467 \mathrm{c}$.

3. Мукан, Н. В. Професійний розвиток учителів загальноосвітніх шкіл у системах неперервної педагогічної освіти Великої Британії, Канади, США [Текст]: дис. ... д-ра пед. наук: спеціальність: 13.00.04 / Н. В. Мукан. - Теорія і методика професійної освіти. К., 2011. - 488 с.

4. Пазюра, Н. В. Внутрішньофірмова професійна підготовка виробничого персоналу в Японії і Південній Кореї [Текст] / Н. В. Пазюра. - К.: Вид-во «Альфа-ПІК», 2014. $-514 \mathrm{c}$.

5. Про основні напрями розвитку трудового потенціалу в Україні на період до 2010 року: Указ Президента України від 03.08.99 р. №958/99 [Електронний pecypc] / Режим доступу:http://zakon.nau.ua/doc/?uid= 1082.3297.0

6. Про заходи щодо сприяння підприємствам в організації професійного навчання кадрів на виробництві: Розпорядження Кабінету Міністрів України від 24 січня 2001 p. № 13-p. [Електронний ресурс] / Київ. - Режим доступу: http://zakon4.rada.gov.ua/laws/show/13-2001-p

7. Наказ № 127/151 від 26.03.2001 «Про затвердження Положення про професійне навчання працівників на виробництві» / Міністерство праці та соціальної політики України, Міністерство освіти і науки України [Електронний ресурс] / Київ. - Режим доступу: http://zakon2.rada.gov.ua/laws/show/z0315-01

8. Концепція розвитку системи підвищення кваліфікації працівників на період до 2010 року: Розпорядження Кабінету Міністрів України від 20 березня 2006 p. № 158 [Електронний ресурс] / Київ. - Режим доступу: http://zakon2.rada.gov.ua/laws/show/158-2006-p

9. Рекомендації щодо стимулювання працівників, які підвищують свою кваліфікацію, затверджено Міністерством праці та соціальної політики України від 3 грудня 2008 р., № 564 [Електронний ресурс] / Режим доступу: http://search.ligazakon.ua/__doc2.nsf/link1/FIN44854.html

10. Вакуленко, О. Набув чинності Закон України «Про професійний розвиток працівників» [Текст] / О. Вакуленко // Довідник кадровика: журнал. - 2012. - № 3. Режим доступу: http://www.kadrovik.ua/content/nabuvchinnost-zakon-ukra-ni-pro-profes-inii-rozvitok-prats-vnik-v

11. Харчук, С. А. Необхідність підготовки та підвищення кваліфікації кадрів на підприємстві в сучасних умовах господарювання [Електронний ресурс] / С. А. Харчук, Я. С. Реморов // Управління персоналом. Режим доступу: http://www.ukr.vipreshebnik.ru/uprpresonal/4462-neobkhidnist-pidgotovki-ta-pidvishchennya- 
kvalifikatsiji-kadriv-na-pidpriemstvi-v-suchasnikh-umovakhgospodaryuvannya.html

12. Закон України «Про професійний розвиток працівників» від 12.01.2012 № 4312-VI. [Електронний pecypc] / Верховна Рада України. - Режим доступу: http://zakon2.rada.gov.ua/laws/show/4312-17

13. У Міносвіти і науки розроблено проект Закону України «Про освіту дорослих» // Урядовий портал: єдиний веб-портал органів виконавчої влади [Електронний ресурс] / Режим доступу: http://www.kmu.gov.ua/control/ publish/article?art_id=21345093

14. Лук'янова, Л. Б. Концептуальні положення освіти дорослих [Електронний ресурс] / Л. Б. Лук'янова. Інститут педагогічної освіти i освіти дорослих АПНУ, 2009. - Режим доступу: http://www.rusnauka.com/ 7_NND_2009/ Pedagogica/43099.doc.htm

15. Андрущенко, В. П. Національна доповідь про стан і перспективи розвитку освіти в Україні [Текст] / В. П. Андрущенко, І. Д. Бех, М. І. Бурда та ін.; за заг. ред. В. Г. Кременя. - Нац. акад. пед. наук України. - К. : Пед. думка, 2011. - $304 \mathrm{c}$.

16. Проект Закону України «Про післядипломну освіту» (з урахуванням пропозицій громадськості) [Текст] / Міністерство освіти і науки країни: офіційний веб-сайт. Київ, 2013. - 22 c. - Режим доступу: http://www.mon.gov.ua/ ua/pr-viddil/1312/1381224620/

\section{References}

1. Bidyuk, N. M. (2009). Teoriya i prakty`ka profesijnogo navchannya bezrobitny ${ }^{` k}$ u SShA [Theory and Practice of Professional Training for the Unemployed in the USA]. Kyiv, 544.

2. Kaplun, A. V. (2011). Rozvytok system pidhotovky kvalifikovanykh robitnykiv u Bolharii i Polshchi (kinets XIXXX st.) [ The Development of Systems of Training Qualified Workforce in Bulgaria and Poland (the end of the XIXXX centuries)]. Kyiv, 467.

3. Mukan, N. V. (2011). Profesiinyi rozvytok uchyteliv zahalnoosvitnikh shkil u systemakh neperervnoi pedahohichnoi osvity Velykoi Brytanii, Kanady, SShA [Professional Development of Secondary School Teachers within the Continuous Pedagogical Education in Great Britain, Canada and the USA]. Kyiv, 488.

4. Paziura, N. V. (2014). Vnutrishnofirmova profesiina pidhotovka vyrobnychoho personalu $\mathrm{v}$ Yaponii i Pivdennii Korei [Organizational Vocational Training of Industry Staff in Japan and Southern Korea]. Kyiv: Alfa PIK, 514.

5. On Main Directions of Labour Potential Development in Ukraine for the Period to 2010: President of Ukraine's Order from 03.08.99 №958/99. Available at: http://zakon.nau.ua/doc/?uid=1082.3297.0
6. On Measures for Encouraging the Organization of Staff Professional Development within Industry: Cabinet of Ministers Order from $24^{\text {th }}$ of January 2001, № 13-p. Kyiv. Available at: http://zakon4.rada.gov.ua/laws/show/13-2001-p

7. Order № 127/151 from 26.03.2001 «On the Vocational Training of Staff within Industry", Ministry of Labour and Social Policy of Ukraine, Ministry of Education and Science of Ukraine, Kyiv. Available at: http://zakon2.rada.gov.ua/laws/show/z0315-01

8. Concept of Development of Employees' Upgrading Qualification System for the Period to 2010: Cabinet of Ministers Order from $20^{\text {th }}$ of January 2006, № 158, Kyiv. Available at: http://zakon2.rada.gov.ua/laws/show/158-2006-p

9. Recommendations on Encouraging Employees who are Improving Their Qualification, Confirmed by Ministry of Labour and Social Policy of Ukraine from $3^{\text {rd }}$ of December 2008, № 564. Available at: http://search.ligazakon.ua/ 1_doc2.nsf/link1/FIN44854.html

10. Vakulenko, O. (2012). Nabuv chynnosti Zakon Ukrainy «Pro profesiinyi rozvytok pratsivnykiv» [On Professional Development of Employees]. Staff Inspector's Reference Book, 3. Available at: http://www.kadrovik.ua/ content/nabuv-chinnost-zakon-ukra-ni-pro-profes-inii-rozvitokprats-vnik-v

11. Kharchuk, S. A., Remorov, Ya. S. Neobkhidnist pidhotovky ta pidvyshchennia kvalifikatsii kadriv na pidpryiemstvi $\mathrm{v}$ suchasnykh umovakh hospodariuvannia [Necessity of Industry Staff Training and Improving Qualification in Current Conditions of Household]. Human Resources Management.

Available at: http://www.ukr.vipreshebnik.ru/upr-presonal/ 4462-neobkhidnist-pidgotovki-ta-pidvishchennya-kvalifikatsijikadriv-na-pidpriemstvi-v-suchasnikh-umovakh-gospodaryuvannya.html

12. Law of Ukraine "On Employees' Professional Development” from 12.01.2012, № 4312-VI. Available at: http://zakon2.rada.gov.ua/laws/show/4312-17

13. Ministry of Education and Science has worked out the Draft of Law of Ukraine "On Adult Education" // Government site. Available at: http://www.kmu.gov.ua/ control/publish/article?art_id=21345093

14. Luk'ianova, L. B. (2009). Kontseptualni polozhennia osvity doroslykh [Conceptual Grounds of Adult Education]. Available at: http://www.rusnauka.com/ 7_NND_2009/Pedagogica/43099.doc.htm

15. National Report on the State and Perspectives of Education Development in Ukraine (2011). National Academy of Pedagogical Sciences of Ukraine. Pedagogichna Dumka, 304.

16. Draft of Law of Ukraine "On Post Diploma Education" (including public proposals) (2013). Ministry of Education and Science of Ukraine, Kyiv, 22.

Рекомендовано до публікації д-р пед. наук, професор Лук'янова Л. Б. Дата надходження рукопису 28.01.2015

Бабушко Світлана Ростиславівна, кандидат філологічних наук, доцент, кафедра української та іноземних мов, Національний університет фізичного виховання і спорту України, вул. Фізкультури, 1, м. Київ, Україна, 03680

E-mail: babushko_sr@mail.ru 